\title{
Biofilm colonizing the Nam Theun 2 power plant Penstock (Lao PDR) - mechanism and potential evolution
}

\author{
Biofilm colonisant la conduite forcée de l'aménagement \\ de Nam Theun 2 (RDP du Laos) - mécanisme et évolution \\ potentielle
}

\author{
S. Pécastaings ${ }^{(1)}$, A. Godon ${ }^{(2)}$, C. Roques ${ }^{(1)}$ \\ (1) Université de Toulouse, UPS, Laboratoire de Génie Chimique, BioSym dpt UMR 5503, \\ Faculté de Pharmacie, 35 chemin des Maraîchers, F-31062 Toulouse cedex 09 \\ sophie@pecastaings.net \\ (2) Nam Theun 2 Power Company Limited (NTPC), Environment \& Social Division - Water Quality \\ and Biodiversity Dept. - Gnommalath Office, PO Box 5862, Vientiane, Lao PDR
}

\begin{abstract}
Biofilms are the most common bacterial life mode on Earth. These tri-dimension bacterial structures occur at a substratum-liquid interface. Due to their intrinsic properties (niche for pathogens, resistance to biocide treatments, etc.), they cause major problems in various industries. In water systems, the physical and chemical characteristics of biofilms (viscoelastic behavior, roughness) may lead to the lowering of flow velocity. A rough biofilm has developed in the Penstock of the Nam Theun 2 hydropower plant (Khammouane Province, Lao PDR). This biofilm is thought to lead to additional head losses and to slightly affect the power production. The mineral, chemical and microbiological compositions of the biofilm were investigated in order to propose solutions to reduce its effect. Samples were taken during two water drainages in 2011 and 2012. In order to complete the knowledge from the water quality monitoring, major elements, trace elements and rare earth element (REE) contents in samples were measured using ICP-AES and ICP-MS. Crystalline phases were identified and quantified by X-ray diffraction (XRD). The microbial composition of the biofilm was first assessed by culture (2011) and then monitored according to the location and the time after water drainage by molecular biology methods (2012). Results show that the chemical composition of the biofilm is dominated by ferric iron $\mathrm{Fe}^{3+}$ and its mineralogy is mostly constituted of lepidocrocite and magnesioferrite. The bacterial population was dominated by beta-Proteobacteria but population profiles varied strongly according to the layer of the biofilm, the nature of the substratum and the time during which the biofilm was subjected to the conditions of the water drainage. These observations are concordant with the modification of the biofilm properties and the reduction in head losses when returning to functioning regimes in the Penstock.
\end{abstract}

Key words - biofilm, head loss, penstock, biofouling, water drainage 
Résumé - Les biofilms représentent la forme de vie bactérienne la plus répandue sur Terre. Ce sont des structures bactériennes tridimensionnelles qui se forment la plupart du temps aux interfaces substrat-liquide. Du fait de leurs propriétés (niche pour micro-organismes pathogènes, résistance aux traitements biocides, etc.), les biofilms causent des problèmes majeurs dans diverses industries. Dans les réseaux d'eau, les caractéristiques physicochimiques des biofilms (comportement viscoélastique, rugosité) peuvent conduire à une diminution du débit. Un biofilm rugueux s'est développé au sein de la conduite forcée de l'aménagement de Nam Theun 2 (Province de Khammouane, Laos). Ce biofilm est suspecté d'engendrer des pertes de charges supplémentaires et de réduire la production d'énergie de manière marginale. Les propriétés minérales, chimiques et microbiologiques du biofilm ont donc été étudiées afin d'envisager des solutions pour diminuer ses effets. Des échantillons ont été prélevés durant deux vidanges en 2011 et 2012. Pour compléter les connaissances provenant du suivi de la qualité de l'eau, les concentrations en éléments majeurs, en traces et en terres rares dans les échantillons globaux ont été mesurées par ICP-AES et ICP-MS. Les phases cristallines ont été identifiées et quantifiées par XRD. La composition microbienne du biofilm a d'abord été analysée par culture (2011), puis, en 2012, par biologie moléculaire à différents sites et en fonction du temps après vidange. Les résultats montrent que la composition chimique du biofilm est dominée par l'ion ferrique $\mathrm{Fe}^{3+}$ et que sa minéralogie est principalement constituée de lépidocrocite et de magnésioferrite. La population bactérienne du biofilm est dominée par les béta-Protéobactéries, cependant, les profils de flores varient fortement en fonction de la couche de biofilm prélevée, de la nature du substrat et de la durée pendant laquelle celui-ci a été soumis aux conditions de vidange de la conduite forcée. Ces observations concordent avec la modification des propriétés du biofilm et la diminution des pertes de charge suite au retour à des conditions de fonctionnement normales dans la conduite forcée.

Mots-clés - biofilm, pertes de charges, conduite forcée, bioencrassement, vidange

\section{INTRODUCTION}

The development of biofilms on the internal walls of hydraulic pipes is a well-described phenomenon. In spite of this, the impact of biofouling on hydraulic performances and overall production efficiency is not well described because of the large diversity of installations. The Nam Theun 2 (NT2) hydropower plant unit (Lao PDR) presents unique specificities to be taken into account: (i) the tropical localization with specific environmental parameters (temperature, relative humidity, etc.; Descloux et al., same issue) influencing the microbiological development and (ii) the large pipe size with seasonal variations of hydraulic parameters. The literature on this topic is dated and mostly qualitative. More recently, Barton et al. (2008) described the biofilm composition on the pipe walls of a hydroelectric plant unit in Tasmania. The predominance of bacteria, and especially alpha-Proteobacteria, corresponds to biofilm characteristics in water systems in temperate zones. Most importantly, authors highlight the role of roughness on the decrease of hydraulic performances. Even though the literature is poor, some reports show the effect of biofilms on near-wall flow (Stoodley et al., 
1998; Schultz \& Swain, 2000) and also link the roughness to the viscoelastic nature of the biofilm. In spite of this, head losses observed in large pipes need further studies. In order to explain the implication of biofilms on industrial sites, the present work consisted in analysing the physical, chemical and microbiological properties of the biofilm formed on the Penstock of the NT2 hydropower plant, where head losses are measurable.

The study was conducted during two missions occurring during two consecutive cool-dry seasons in 2011 and 2012. During these periods, outages were performed allowing biofilm observations and samplings. In 2011, the campaign consisted in a physical and chemical characterization of the Intake water and the mineralization of the biofilm. Classical microbiological analyses of the biofilm (culture) were done and emphasized the importance of improving the microbial profiles analysis in order to better characterize the biofilm. This was achieved in 2012, taking into account (i) the different parts of the Penstock and the nature of the pipe walls and (ii) the impact of outages and water drainages. These observations were correlated with the physical and chemical characterization performed in 2011.

The main part of biofilm control literature describes chemical or physical treatments that are unrealistic in the present context. The low flexibility of the system (difficult access and size of the Penstock, release of water in the environment) prevents the use of chemical and abrasive treatments to remove the biofilm. The final aim of this project was to evaluate and suggest solutions to monitor and limit biofilm development in order to avoid increases of head losses. A focus was made on the impact of water drainage on the biofilm removing/stabilization.

\section{MATERIALS AND METHODS}

\subsection{Sampling sites}

Inside the Penstock, two sampling sites for chemical, mineralogy and microbiology studies were chosen during the first Penstock water drainage, from January 22nd to January 29th, 2011. Supplemental samples for microbiology studies were taken during the second Penstock water drainage, from January 14th to January 16th, 2012 at these two sites. The first site, HR, refers to the Headrace section. This section is made of reinforced concrete. The Penstock is $9.2 \mathrm{~m}$ in diameter with a slope of $0.5 \%$. The pressure is at 11.5 bars and the water velocity is $4.7 \mathrm{~m} \mathrm{~s}^{-1}$. The second site, HP, refers to the High Pressure section (Fig. 1). The junction between concrete and galvanized steel pipes, coated with an anti-corrosive paint (protecting coat), is accessible at this site. The steel pipe was coated to prevent corrosion. The paint consists in 2 layers: an epoxy primer enriched in zinc (Epicon Zinc HB-2, Toa Chugoku, Japan) and an epoxy top coat (Biscon HB, Toa Chugoku, Japan), both diluted with CMP-31 thinner. The Penstock is $7.15 \mathrm{~m}$ in diameter with a slope of $1.1 \%$. The pressure is at 34 bars and the water velocity is $7.8 \mathrm{~m} \mathrm{~s}^{-1}$. Mineralogical and microbiological samplings were taken within a length of less than $5 \mathrm{~m}$, a negligible distance compared to 


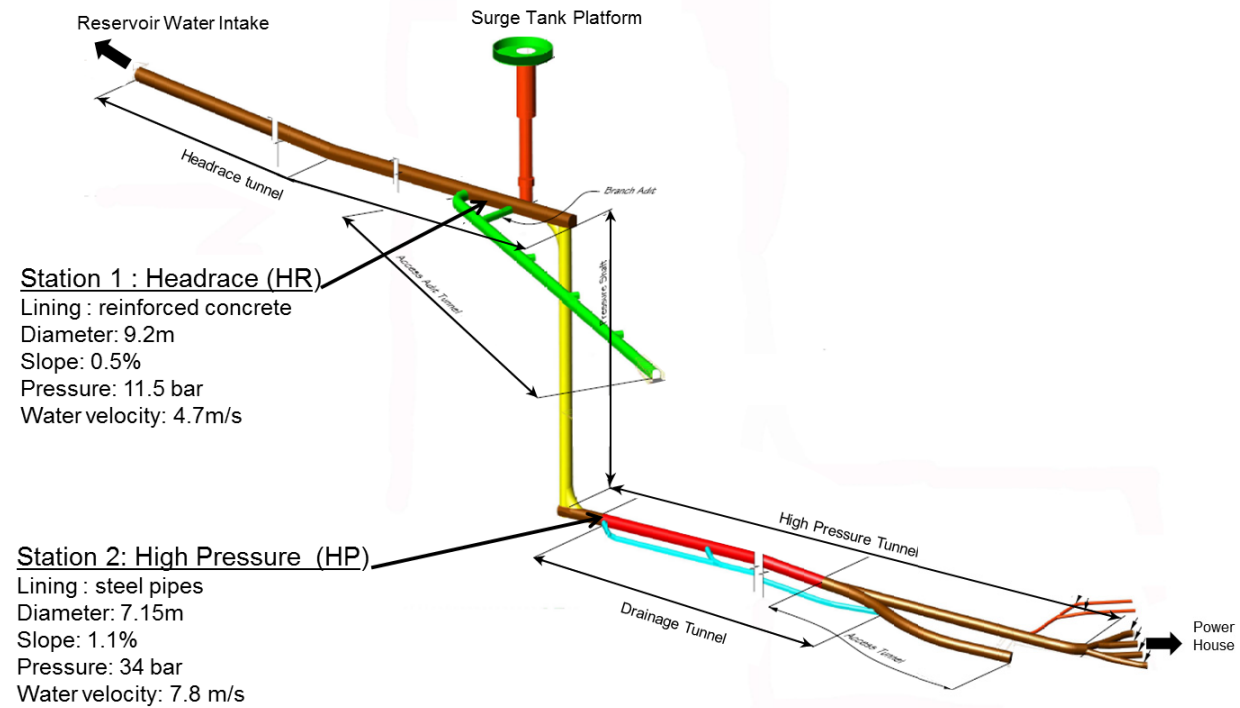

Fig. 1. Sampling sites.

Fig. 1. Points de prélèvements.

the length of Penstock (more than $2.8 \mathrm{~km})$.

The physical and chemical properties of the water have been monitored since 2009 by the NT2 Aquatic Environment Laboratory (AE Lab, NTPC) at the Intake (site RES9 in the Headrace Channel of the NT2 Reservoir) and at the outlet of the Power House in the Tailrace Channel (site TRC1). Extended details of this monitoring can be found in Chanudet et al. (same issue). Thus, RES9 was also chosen for microbiological samplings.

\subsection{Sampling methods}

\subsubsection{Mineralogical samplings}

One sample was collected on each site using a pre-cleaned large spatula.
Cleaning was achieved using fuming $\mathrm{HNO}_{3}$ and rinsing with pure water (electrical conductivity measured at $0.055 \mu \mathrm{S} \mathrm{cm}^{-1}$ ) obtained from a brand new batch of filtered and deionized distilled water (Schott Water Distilling Apparatus Typ 82000 combined with an Elga PureLab Ultra Analytic MK2 equipped with two ion exchange cartridges, a UV lamp and a micron filter). One kilogram of sludge/biofilm material was collected and preserved in a large mouth $1 \mathrm{~L}$ pre-cleaned Nalgene bottle. Since the sludge was thin at both sites (from 1 to $5 \mathrm{~mm}$ ), each sample corresponds to a large surface: $50 \times 50 \mathrm{~cm}$ at the HR site and $60 \times 300 \mathrm{~cm}$ at HP site, respectively. Samples in Nalgene bottles were stored in darkness at approximately $10^{\circ} \mathrm{C}$ and transported to ALS Minerals service laboratory in Vientiane (Lao PDR). 
Table I. Samples taken during the 2012 water drainage.

Tableau I. Échantillons prélevés pendant la vidange de 2012.

\begin{tabular}{|c|c|c|c|}
\hline Date & Site & Surface & Sample's description \\
\hline 14th of January & HR & Concrete & Top part of biofilm \\
\hline 14th of January & HR & Concrete & Complete biofilm \\
\hline 15th of January, morning & $\mathrm{HP}$ & Concrete & Top part of biofilm \\
\hline 15th of January, morning & HP & Concrete & Complete biofilm \\
\hline 15th of January, morning & HP & Galvanized Steel & Complete biofilm \\
\hline 15th of January, afternoon & $\mathrm{HR}$ & Concrete & Top part of biofilm \\
\hline 15th of January, afternoon & $\mathrm{HR}$ & Concrete & Complete biofilm \\
\hline 16th of January & HP & Concrete & Complete biofilm \\
\hline 16th of January & HP & Galvanized steel & Complete biofilm \\
\hline 21st of January & $\begin{array}{l}\text { Intake, } \\
\text { RES9 }\end{array}$ & - & $\begin{array}{l}100 \mathrm{~mL} \text {, bottom of the water } \\
\text { column at the Intake }\end{array}$ \\
\hline 21st of January & $\begin{array}{l}\text { Intake, } \\
\text { RES9 }\end{array}$ & - & $\begin{array}{l}100 \mathrm{~mL}, \text { middle of the water } \\
\text { column at the Intake }\end{array}$ \\
\hline
\end{tabular}

\subsubsection{Microbiological samplings}

Two samples were taken in duplicate during the 2011 sampling campaign at both HR and HP sites. During the 2012 water drainage, nine samples were made in duplicate (Tab. I). After the water drainage, two water samples were collected at the Intake RES9). Biofilm was sampled with a sterile spatula and transferred immediately in sterile bottles.

\subsection{Physical, chemical and mineralogical analysis}

Density measurements were done with a pycnometer on a $3 \mathrm{~g}$ aliquot. The moisture percentage was determined by a gravimetric procedure after dehydration of another aliquot at $105{ }^{\circ} \mathrm{C}$. Finally, few aliquots of at least $1 \mathrm{~g}$ of sample were dried and the solid residue was crushed into fine powder.

Aliquots of powders were then sent to ALS Minerals service laboratory in Brisbane (Australia) for chemical composition and mineralogical analyses. Total Carbon and Total Sulfur contents were individually analysed with a Leco furnace. The total volatile constituents portion of the samples was also measured using the fraction lost on ignition (LOI data) after combustion at $1000^{\circ} \mathrm{C}$. An aliquot of powder $(0.5 \mathrm{~g})$ was prepared by digestion with strong acids and analysed either by ICP (Inductively Coupled Plasma)-AES (Atomic Emission Spectrometry) or ICP-MS (Mass Spectrometry), both with ultra-low detection limits, to obtain some major and minor elements ( $\mathrm{Al}, \mathrm{Fe}, \mathrm{Ca}, \mathrm{Mg}$, $\mathrm{Na}, \mathrm{K}, \mathrm{Cr}, \mathrm{Ti}, \mathrm{Mn}$ and $\mathrm{P}$ ) and an extended overview on REE (Rare Earth Element) and trace elements 
(focusing on heavy metals). Another powder sample $(2 \mathrm{~g})$ was used for lithium borate fusion to prepare the sample for a whole rock analysis performed by ICP-AES, which provided major and minor constituents, reported as oxides $\left(\mathrm{SiO}_{2}, \mathrm{Al}_{2} \mathrm{O}_{3}, \mathrm{FeO}, \mathrm{Fe}_{2} \mathrm{O}_{3}, \mathrm{CaO}, \mathrm{MgO}\right.$, $\mathrm{Na}_{2} \mathrm{O}, \mathrm{K}_{2} \mathrm{O}, \mathrm{Cr}_{2} \mathrm{O}_{3}, \mathrm{TiO}_{2}, \mathrm{MnO}, \mathrm{P}_{2} \mathrm{O}_{5}$, $\mathrm{SrO}, \mathrm{BaO}$ and completed to $100 \%$ using LOI) according to a theoretical sequence of crystallization. Mineralogical phases were identified using powder X-ray diffraction (XRD) on pellets (PANalytical vertical diffractometer, copper $\mathrm{K}$ radiation). XRD results are nominal (Rietveld technique with the software SiroQuant V3, Sietronics Pty Ltd). Non-diffracting or unidentified phase was discarded (Jade V9.0, Materials Data Inc.).

\subsection{Microbiological analysis}

\subsubsection{Culture of biofilm samples and} isolates description - 2011 campaign

The 2011 campaign was a preliminary study to design the future molecular biology study. The objective was to have an idea of the level of bacteria present in the biofilm. Hence, only one generic growth medium (Trypcase Soy Agar - TSA) was used.

Frozen biofilm samples supplemented with glycerol $(30 \% \mathrm{v} / \mathrm{v})$ were sent to the Laboratory of Paul Sabatier University (Toulouse, France) for microbiological analyses, since those analyses were not feasible in the Laos laboratory. Once gently thawed, volumes of $0.1 \mathrm{~mL}$ and $1 \mathrm{~mL}$ were spread on TSA (bioMérieux, Marcy-l'Étoile, France) and incubated at 22.5, 30.0, $37.0^{\circ} \mathrm{C}$ under aerobic condition and $37.0{ }^{\circ} \mathrm{C}$ under anaerobic condition. After $48 \mathrm{~h}$, the macroscopic description of the colonies was used to determine major bacterial types on each plate. These colonies were subcultured on a fresh TSA plate. After $48 \mathrm{~h}$ of incubation in the same condition as previously used, a Gram staining, an oxidase test and catalase test were performed.

\subsubsection{Microscopic observations - 2012 campaign}

Microscopic observations were made at the Nam Theun 2 Power Company (NTPC) Laboratory (AE Lab) immediately after sampling during the 2012 campaign. Samples were diluted in Trypan blue, a vital dye that stains only dead cells. The counting of viable and dead cells was performed using a Malassez cell, using microscope equipped with $a \times 100$ objective. The quantification limit of this method is $10^{6}$ cells per grams $(\mathrm{g})$ of biofilm.

\subsubsection{Quantification of main bacterial} groups and establishment of bacterial profiles - 2012 campaign

\subsubsection{DNA extraction}

DNA was extracted in duplicate from each biofilm and water sample from the 2012 campaign, with the UltraClean Soil DNA isolation kit (Mo-Bio, Carlsbad, CA, USA). $250 \mathrm{mg}$ of biofilm samples were transferred in microtubes containing the lysis buffer and microbeads provided by the manufacturer. A negative extraction sample was made with $200 \mu \mathrm{L}$ of sterile water. $60 \mu \mathrm{L}$ of $\mathrm{S} 1$ solution and $200 \mu \mathrm{L}$ of IRS 
solution were added in each tube before vortexing at maximum speed for $10 \mathrm{~min}$. After centrifugation $(10000 \mathrm{~g}$, $30 \mathrm{~s}), 250 \mu \mathrm{L}$ of $\mathrm{S} 2$ solution were added to the supernatant and the mix was incubated $5 \mathrm{~min}$ at $4{ }^{\circ} \mathrm{C}$. After centrifugation $(10000 \mathrm{~g}, 1 \mathrm{~min}), 450 \mu \mathrm{L}$ of supernatant were mixed with $900 \mu \mathrm{L}$ of S3 solution and this mixture was transfered on a silica column to bind the DNA. $300 \mu \mathrm{L}$ of $\mathrm{S} 4$ solution were used to wash the column and purify the DNA. Finally, the DNA was eluted using $200 \mu \mathrm{L}$ of $\mathrm{S} 5$ solution and centrifugating the columns at $10000 \mathrm{~g}$ for $30 \mathrm{~s}$. DNA samples were immediately frozen $\left(-20^{\circ} \mathrm{C}\right)$. They were sent to the Laboratory (Paul Sabatier University, Toulouse, France) under this condition. One sample (a duplicate of the HR complete biofilm taken on the 15th of January 2012) was lost during transfer from Lao PDR to France.

Water samples $(100 \mathrm{~mL})$ were thawed and filtered on polycarbonate membranes (porosity $=0.2 \mu \mathrm{m}$ ) to collect bacteria from the samples. Membranes were transfered in microtubes containing the lysis buffer and microbeads provided by the manufacturer. The same extraction protocole was applied as for biofilm samples.

\subsubsection{Quantification of main bacterial groups by qPCR}

The qPCR was run on MyiQ Real Time PCR Detection (BioRad, Marnesla-Coquette, France), in 96-well microplates. In this study, the proportion of Bacteria, alpha-Proteobacteria, betaProteobacteria, gamma-Proteobacteria, Bacteroidetes, Firmicutes, Actinobacteria, Acidobacteria was quantified in biofilm and water samples. Only eukaryotic fungal cells (Fungi) were quantified, and not total Eukaryotic cells (Algae or Protozoa). A sequence of the 16S rRNA gene (for Bacteria) or 18S rRNA gene (for Fungi), specific of each group and already described in the literature, was targeted (Tab. II).

The qPCR mixture $(25 \mu \mathrm{L}$ per well) contained $12.5 \mu \mathrm{L}$ of iQ SYBR Green Supermix (2X, BioRad), $350 \mathrm{nmol} \mathrm{L}-1$ of each forward and reverse primers (Life Technologies, Villebon-sur-Yvette, France), $5 \mu \mathrm{L}$ of sample (or standard) DNA. Each sample was analysed in triplicate. Two negative controls were made for each qPCR run: one with $5 \mu \mathrm{L}$ of PCR grade sterile water instead of DNA sample and one with the negative extraction control. A positive control was made for each sample by adding $1 \mu \mathrm{L}$ of internal inhibition control into the mixture to monitor QPCR inhibition. The amplification was achieved after a 10 min activation step at $95^{\circ} \mathrm{C}$ and the amplification cycle $\left(15 \mathrm{~s}\right.$ at $95^{\circ} \mathrm{C}, 30 \mathrm{~s}$ at hybridization temperature and $30 \mathrm{~s}$ at $72{ }^{\circ} \mathrm{C}$ ) was repeated 40 times. SYBR Green Fluorescence was monitored in the wells after each amplification cycle.

Standard DNA curves were obtained for each target group after purification of genomic DNA from reference strains (Tab. III). DNA was quantified by measuring absorbance at $260 \mathrm{~nm}$, assuming that 1 absorbance unit corresponds to a concentration of $50 \mathrm{ng} \mathrm{LL}^{-1}$. Genomic DNA concentration was deduced according to the genome size of bacterial species used for the study and considering that 1 base pair = $660 \mathrm{~g} \mathrm{~mol}^{-1}$.

Serial dilutions of standard genomic DNAs were made with elution buffer 
Table II. Primers used for qPCR.

Tableau II. Amorces utilisées pour la qPCR.

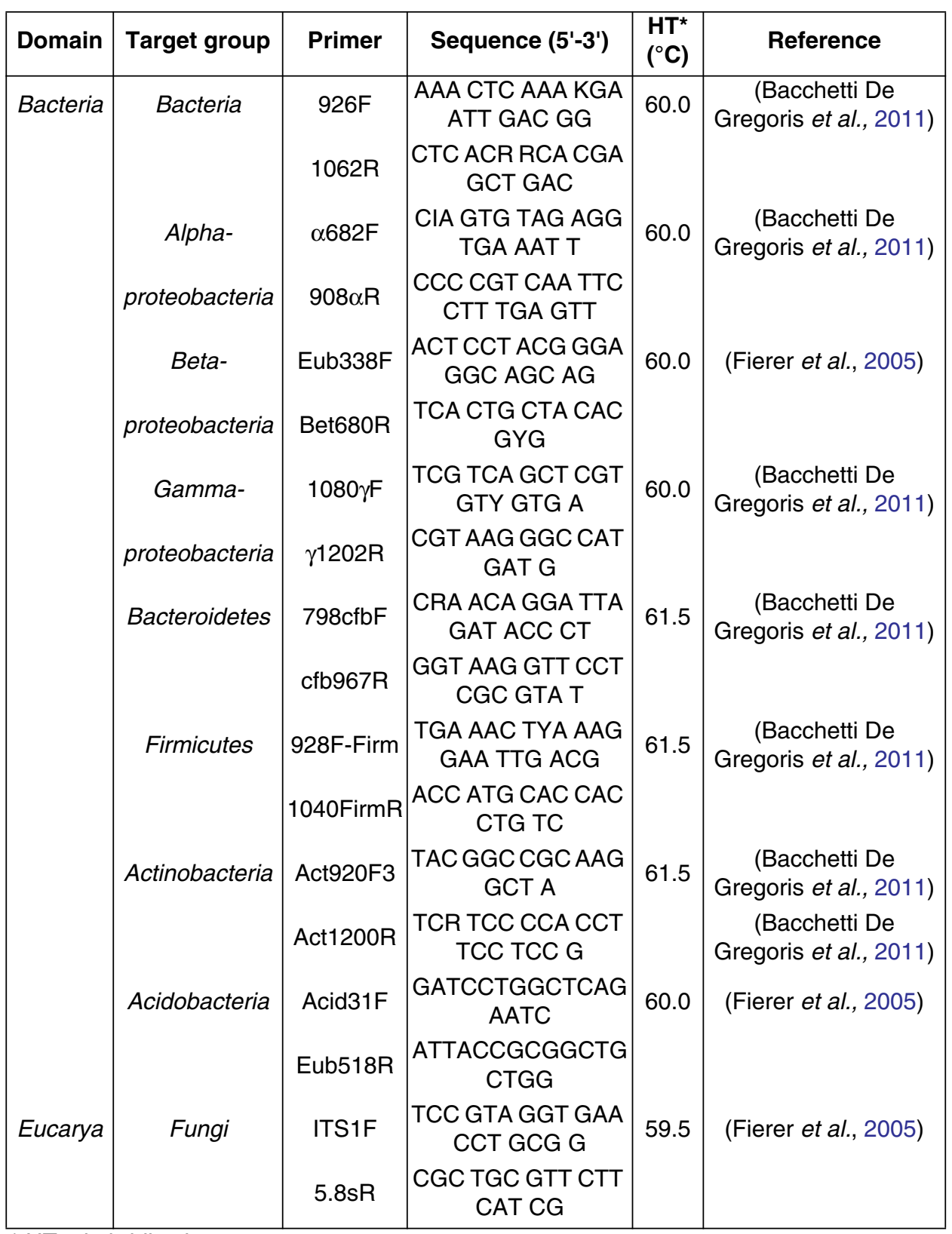

${ }^{*} \mathrm{HT}=$ hybridization temperature 
Table III. Reference strains.

Tableau III. Souches de références.

\begin{tabular}{|c|c|c|}
\hline Domain & Target group & Strain \\
\hline \multirow[t]{16}{*}{ Bacteria } & Bacteria & Escherichia coli \\
\hline & & (CIP54.8T) \\
\hline & Alpha- & Brevundimonas diminuta \\
\hline & proteobacteria & (CIP 103020) \\
\hline & Beta- & Burkholderia cepacia \\
\hline & proteobacteria & (ATCC 24416) \\
\hline & Gamma- & Escherichia coli \\
\hline & proteobacteria & (CIP54.8T) \\
\hline & Bacteroidetes & Bacteroides fragilis \\
\hline & & (ATCC25285) \\
\hline & Firmicutes & Staphylococcus epidermidis \\
\hline & & (CIP6821) \\
\hline & Actinobacteria & Microccus luteus \\
\hline & & (ATCC 9341) \\
\hline & Acidobacteria & Acidobacterium capsulatum \\
\hline & & (DSM11244) \\
\hline Eucarya & Fungi & Saccharomyces cerevisiae subspecies boulardii \\
\hline
\end{tabular}

(from Ultraclean Soil DNA extraction kit) to prepare standard ranges of DNA from 5 to $50000 \mathrm{gu}$ (genome units) per $\mu \mathrm{L}$. Each run of qPCR was conducted with standard DNA (5 points in triplicate), 2 negative PCR controls and 2 negative extraction controls (DNA extraction of sterile water) and samples. After completion of qPCR, the standard curves were constructed by plotting threshold cycles (Ct) values versus the log quantity of standard DNA in a well. Results are an average of qPCR triplicate results, expressed in log gu per gram of biofilm (or per $100 \mathrm{~mL}$ of water in case of liquid samples).
Since the quantification limit is $5 \mathrm{gu}$ in $25 \mu \mathrm{L}$ of PCR mix, the quantification limit in biofilms is $1350 \mathrm{gu} \mathrm{g}^{-1}$ of biofilm and $220 \mathrm{gu} 100 \mathrm{~mL}^{-1}$ of water. Results are expressed as percentages of each group amongst total Bacteria in each sample duplicate. Proportion averages were calculated and plotted in graphs that represent the bacterial population profiles.

It is important to note here that qPCR gives information on the presence of microorganisms in a sample, but does not give indication about their viability (dead or alive). Viability studies were made by microscopic analysis. 


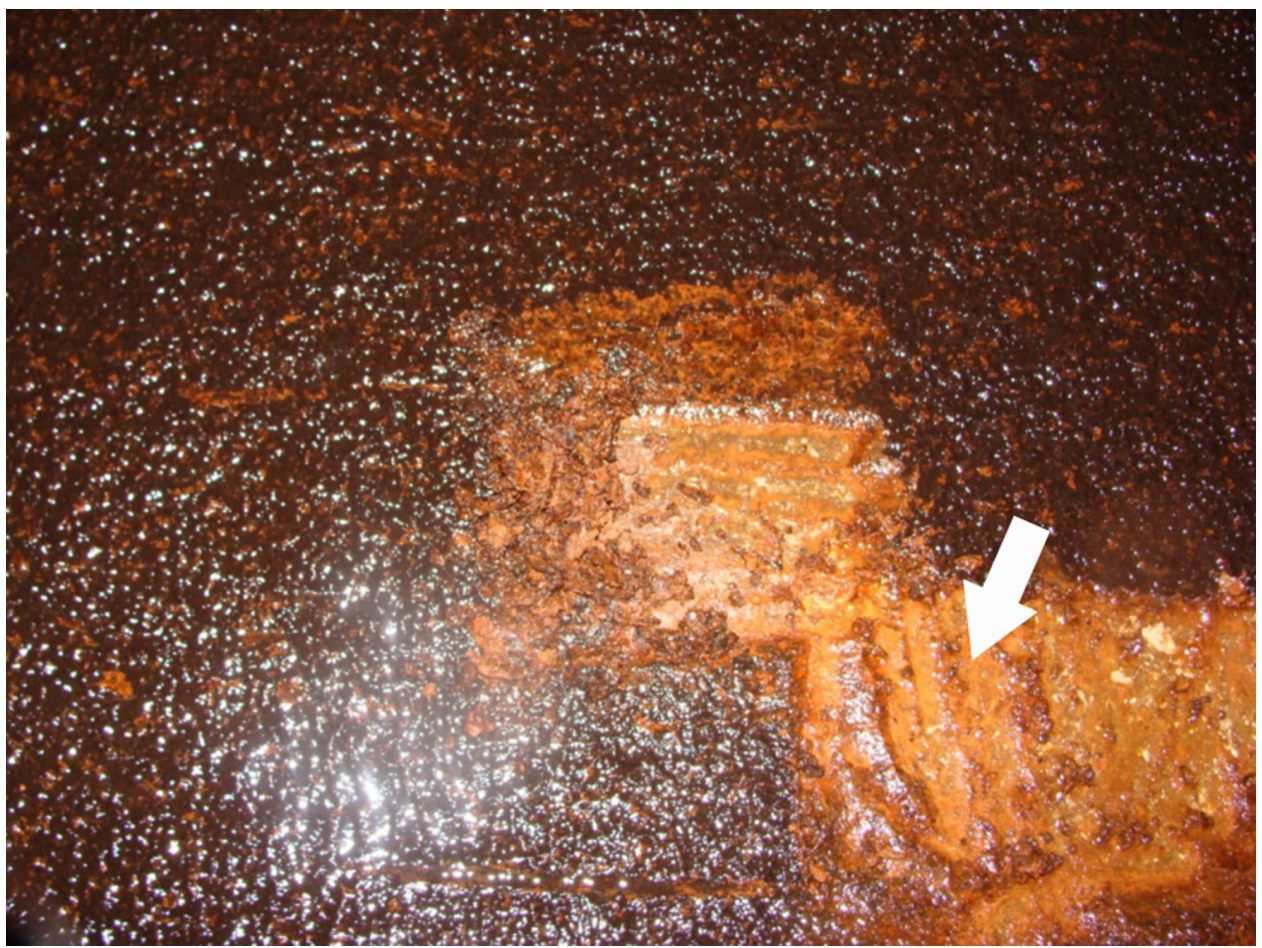

Fig. 2. Biofilm on the concrete HR Tunnel. The white arrow indicates biofilm removal after sampling. Fig. 2. Biofilm formé sur le Tunnel HR. La flèche blanche indique le détachement après prélèvement du biofilm.

\section{RESULTS}

\subsection{Macroscopic field observations -2011 \& 2012 campaigns}

The biofilm covering the Penstock in the HR section appeared to be uniform. The deposit contained nodular concretion of a few millimetres in size. Its thickness reached a maximum of $5 \mathrm{~mm}$. Colour varied from black to red and yellowish (Fig. 2) possibly indicating the presence of iron oxides. This sludge material was sticky but not strongly fixed onto the inner walls of the Tunnel. It was easy to detach by patch from the concrete. No difference was observed according to the curve of the Tunnel. The deposit was similar everywhere in the HR section.

On the HP section, the biofilm was different from the HR site. The deposit looked also like a nodular concretion but contained smaller nodules (maximum of 1 to $2 \mathrm{~mm}$ ). On the HP section, the junction between the concrete and galvanized material (with anti-corrosive painting) is accessible. A macroscopic difference between the biofilm formed on both surfaces was clearly noted (Fig. 3): the biofilm was thinner (2 to $3 \mathrm{~mm}$ ) on the galvanized steel and less 


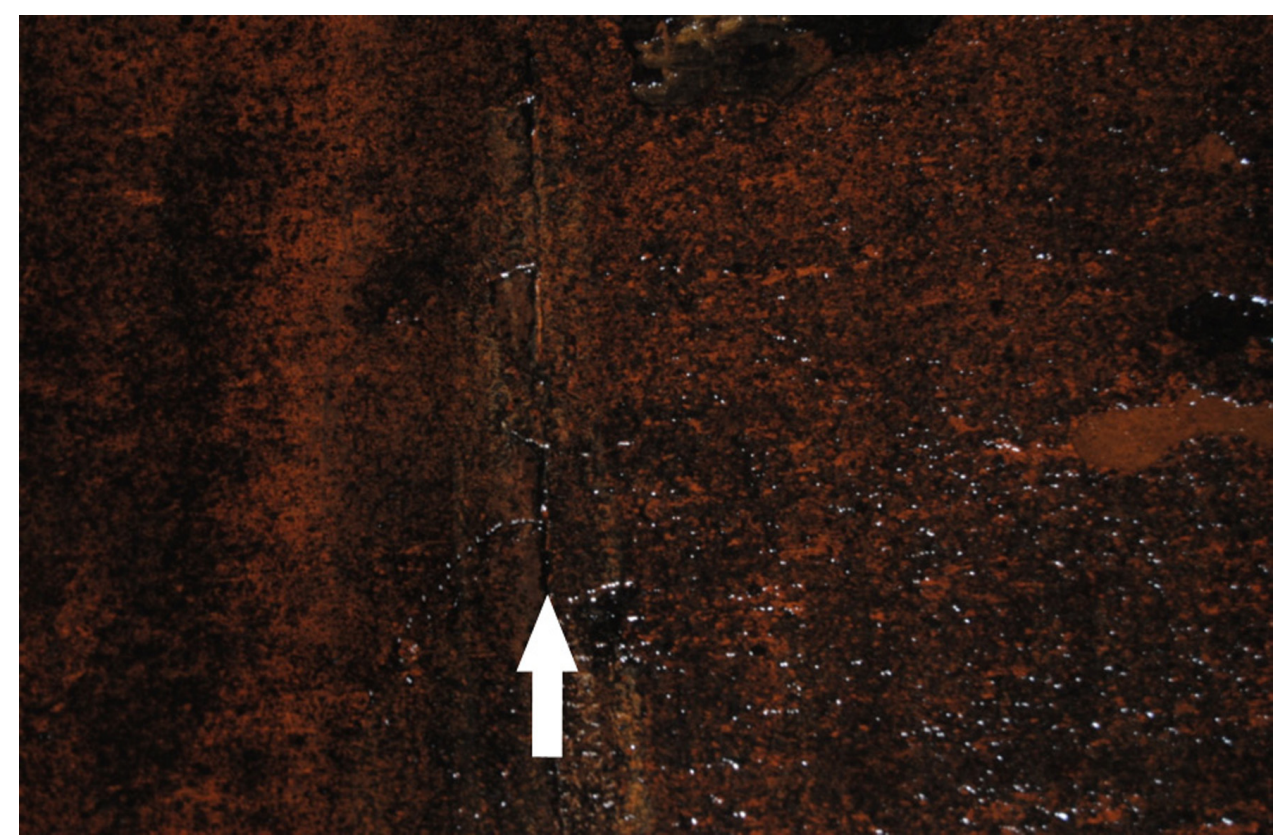

Fig. 3. Biofilm on the galvanized steel (left) and the concrete part (right) of the HP site. The white arrow shows the separation between both zones.

Fig. 3. Biofilm formé sur les parties en acier galvanisé (à gauche) et en béton (à droite) de la conduite au niveau du site HP. La flèche blanche indique la séparation entre les deux zones.

rough. Colour varying from black to red and yellowish was also observed. Similarly to the HR site, this sludge material was very wet. It also appeared that the concrete biofilm was constituted of 2 layers. The upper layer was highly hydrated, viscous and easily detached and suspended in water. The bottom layer was mineralized, rougher and also more difficult to detach than the upper layer.

\subsection{Intake water physical and chemical properties}

The water quality monitoring has been extensively described in Chanudet et al. (same issue). Reservoir water is carbonated and shows low content of $\mathrm{Si}$, in coherence with the regional geologic sedimentary setting. Iron content is in the range of 0 to $3 \mathrm{mg} \mathrm{L}^{-1}$ and predominantly occurs as dissolved ferrous iron $\mathrm{Fe}^{2+}$, with only $10 \%$ as $\mathrm{Fe}^{3+}$. Since the beginning of test operation in March 2010, the water column at RES9 has been homogeneous (Tab. IV).

RES9 and TRC1 are close in terms of chemical composition and it looks like nothing much happened in between (i.e.: in the Penstock and all the plumbing system of the Power House) besides the increase of pressure up to 34 bars (which may change the thermodynamics of the chemical equilibriums) and its fast return to atmospheric pressure. 
Table IV. Typical chemical composition of the water at RES9 and TRC1 in January 2011. Table IV. Composition chimique typique de l'eau à RES9 et TRC1 en janvier 2011.

\begin{tabular}{|l|c|c|c|c|}
\hline Parameter (Unit) & RES9 Surface & RES9 Middle & RES9 Bottom & TRC1 \\
\hline Depth (m) & 0.2 & 8.0 & 16.0 & 0.2 \\
$\mathrm{Si}\left(\mathrm{mg} \mathrm{L}^{-1}\right)$ & 2.35 & 2.28 & 2.63 & 2.36 \\
$\mathrm{Fe}^{2+}\left(\mathrm{mg} \mathrm{L}^{-1}\right)$ & 0.14 & 0.30 & 0.24 & 0.20 \\
$\mathrm{Fe}^{3+}\left(\mathrm{mg} \mathrm{L}^{-1}\right)$ & 0.17 & $<0.10$ & 0.48 & $<0.10$ \\
$\mathrm{TOC}\left(\mathrm{mg} \mathrm{C} \mathrm{L}^{-1}\right)$ & 1.78 & - & 1.30 & 1.75 \\
$\mathrm{Ca}\left(\mathrm{mg} \mathrm{L}^{-1}\right)$ & 3.68 & 3.40 & 3.42 & 3.40 \\
$\mathrm{Mg}\left(\mathrm{mg} \mathrm{L}^{-1}\right)$ & 0.90 & 0.85 & 0.85 & 0.75 \\
$\mathrm{Na}\left(\mathrm{mg} \mathrm{L}^{-1}\right)$ & 0.89 & 0.88 & 0.86 & 0.93 \\
$\mathrm{~K}\left(\mathrm{mg} \mathrm{L}^{-1}\right)$ & 0.89 & 0.85 & 0.81 & 0.96 \\
$\mathrm{SO}_{4}{ }^{2-}\left(\mathrm{mg} \mathrm{S} \mathrm{L}^{-1}\right)$ & 0.59 & 0.54 & 0.59 & 0.73 \\
$\mathrm{PO}_{4}{ }^{3-}\left(\mathrm{mg} \mathrm{P} \mathrm{L}^{-1}\right)$ & $<0.03$ & $<0.03$ & $<0.03$ & $<0.03$ \\
\hline
\end{tabular}

\subsection{Chemical composition} and mineralogy of the sludge

Results on both samples are summarized in Table $\mathrm{V}$. The moisture percentage reveals that both samples are highly hydrated, and that sample from HP site is richer in water than the one from HR site. This is consistent with field observations (see Sect. 3.1.).

The sludge is dense, with a specific gravity near 3 . Even though the samples could have been shaken and compacted during their transportation to Vientiane, it means that the dry matrix is highly dense, in agreement with heavy metals loads.

LOI is too high ( 20\%) to be solely explained by volatile constituents from the organic matter, the carbonated phases or salts, since the sum of $\mathrm{C}$ and $\mathrm{S}(\sim 7 \%$ maximum) is far from reaching the LOI content. Moreover, $\mathrm{Ca}$ and $\mathrm{Mg}$ concentrations are too low to involve a significant quantity of carbonated constituents in the sludge. $\mathrm{HCl}$ test performed on a small aliquot of sludge at the laboratory right after the sampling did not show any effervescence. Nevertheless, high LOI can be explained by the presence of many hydroxides.

The chemical composition is dominated by the iron content, which is the most important element (almost $50 \mathrm{wt} . \%$ ), and occurs mainly as ferric iron $\mathrm{Fe}^{3+}$. Other elements are lower in concentrations, except oxygen, which is the element bounding minerals and thus was not analysed by these techniques. $\mathrm{Si}, \mathrm{Al}, \mathrm{Ca}, \mathrm{Mg}, \mathrm{Na}, \mathrm{K}, \mathrm{Cr}, \mathrm{Ti}, \mathrm{Mn}$ and $P$ are present in minor amounts (Tab. V). Trace elements and REE are negligible. Such a chemical composition differs from any precipitation of previously dissolved rocks, because it does not fit the geologic setting dominated by sandstones and carbonated sedimentary rocks. The source of the HR Tunnel sludge is unlikely to be the 
Table V. Chemical and phase compositions of the sludge at HR and HP sites. Table V. Composition chimique et minéralogique du biofilm des sites HR et HP.

\begin{tabular}{|c|c|c|}
\hline $\begin{array}{l}\text { Parameter } \\
\text { (unit) }\end{array}$ & HR & HP \\
\hline $\mathrm{SiO}_{2}$ (wt.\%) & 3.68 & 10.40 \\
\hline $\mathrm{Al}_{2} \mathrm{O}_{3}$ (wt.\%) & 1.13 & 3.62 \\
\hline Al (wt.\%) & 0.46 & 0.87 \\
\hline $\mathrm{FeO}$ (wt.\%) & 0.50 & 2.42 \\
\hline $\mathrm{Fe}_{2} \mathrm{O}_{3}$ (wt.\%) & 76.6 & 59.9 \\
\hline $\mathrm{Fe}$ (wt.\%) & 48.4 & 41.1 \\
\hline $\mathrm{CaO}$ (wt.\%) & 0.77 & 0.82 \\
\hline $\mathrm{Ca}$ (wt.\%) & 0.47 & 0.56 \\
\hline MgO (wt.\%) & 0.21 & 0.59 \\
\hline Mg (wt.\%) & 0.09 & 0.18 \\
\hline $\mathrm{Na}_{2} \mathrm{O}$ (wt.\%) & 0.05 & 0.08 \\
\hline $\mathrm{Na}$ (wt.\%) & 0.02 & 0.03 \\
\hline $\mathrm{K}_{2} \mathrm{O}$ (wt.\%) & 0.09 & 0.43 \\
\hline K (wt.\%) & 0.03 & 0.08 \\
\hline $\mathrm{Cr}_{2} \mathrm{O}_{3}$ (wt.\%) & $<0.01$ & $<0.01$ \\
\hline $\mathrm{Cr}(\mathrm{ppm})$ & 20 & 30 \\
\hline $\mathrm{TiO}_{2}$ (wt.\%) & 0.03 & 0.14 \\
\hline $\mathrm{Ti}$ (ppm) & 130 & 90 \\
\hline MnO (wt.\%) & 0.59 & 1.84 \\
\hline Mn (ppm) & 3730 & 13550 \\
\hline SrO (wt.\%) & 0.01 & 0.01 \\
\hline Sr (ppm) & 52 & 45 \\
\hline $\mathrm{BaO}$ (wt.\%) & 0.02 & 0.03 \\
\hline $\mathrm{Ba}(\mathrm{ppm})$ & 182 & 310 \\
\hline $\mathrm{P}_{2} \mathrm{O}_{5}$ (wt.\%) & 0.07 & 0.14 \\
\hline P (ppm) & 130 & 340 \\
\hline S (wt.\%) & 0.06 & 0.11 \\
\hline C (wt.\%) & 3.00 & 7.09 \\
\hline LOI (wt.\%) & 16.65 & 21.80 \\
\hline Moisture (wt.\%) & 72.3 & 90.4 \\
\hline Density & 2.97 & 3.03 \\
\hline Phase & Lepidocrocite (100\%) & $\begin{array}{c}\text { Lepidocrocite (64\%) } \\
\text { Magnesioferrite (23\%) } \\
\text { Quartz (9\%) }\end{array}$ \\
\hline
\end{tabular}


lining of the Headrace Channel, since it has a different chemical composition (mainly Quartz $\mathrm{SiO}_{2}$; $\mathrm{AE}$ Lab. unpublished data, 2010). The whole rock analysis revealed that the most important group of minerals is iron oxides and hydroxides, because $\mathrm{Fe}_{2} \mathrm{O}_{3}$ and LOI are very high.

These results are consistent with XRD patterns and phase occurrences (Tab. V). Lepidocrocite, an iron oxidehydroxide $(\gamma-\mathrm{FeO} . \mathrm{OH}$ composed of $\mathrm{Fe}^{3+}$; density 4.09), scales easily and shows red to yellowish to blackish brown macroscopic natural colour. It originates mainly from the weathering of primary iron minerals or rust from steel water pipes. Magnesioferrite is an iron oxide $\left(\mathrm{MgFe}_{2} \mathrm{O}_{4}\right.$ also composed of $\mathrm{Fe}^{3+}$; density 4.52) occurring as massive or granular of well-formed fine sized crystals, brownish black to black in colour. Finally, Quartz $\left(\mathrm{SiO}_{2}\right.$; density 2.65) is ubiquitous (Deer et al., 2013). These results are in good agreement with field observations. Background level of the powder XRD patterns are quite high and suggest that the samples are both disordered, the sludge from HP site being relatively more crystallized than the one from HR site. Since the chemical composition of the sludge fits its mineralogy, it is possible that the non-crystalline material is an amorphous material analogous of the phases identified. This disordered part of the sludge could also be very dense.

\subsection{Bacterial population profiles}

Bacterial profiles were used as a tool to characterize the biofilm in the different parts of the Penstock. Fungi were analysed in every water and biofilm samples, however they were only detected in low quantities, close or inferior to the quantification limit. This result was consistent with microscopic observations (data not shown). Since Bacteria were highly predominant, calculating the ratio between Bacteria and Fungi was irrelevant. Results presented here are expressed in terms of bacterial profiles only.

Only the main constitutive groups of the Penstock biofilm were analysed. Since the Penstock is fed with reservoir water, taxa representative of surface water and soil were targeted. Proteobacteria (Gram-negative) are the wider and most diversified bacterial groups. They include alpha-Proteobacteria, beta-Proteobacteria and gamma-Proteobacteria, delta-Proteobacteria and epsilon-Proteobacteria. Delta-Proteobacteria and epsilon-Proteobacteria were not studied here. Actinobacteria (Gram-positive bacteria with high $\mathrm{G}+\mathrm{C}$ content) are very abundant in soils and have the capacity to degrade a wide variety of organic compounds. The 2011 culture analysis showed the presence of filamentous Gram-positive bacilli and catalase-positive cocci that could belong to that group. Firmicutes (Grampositive with a low $\mathrm{G}+\mathrm{C}$ content) have the capacity to produce endospores and are often free saprophytic bacteria. Bacteroidetes (Gram-negative other than Proteobacteria) are anaerobic nonsporulated bacteria isolated mostly in oral cavity and intestinal tracts. The group of Acidobacteria (Gram-negative other than Proteobacteria) was recently discovered and is still not very well known. These microorganisms are 


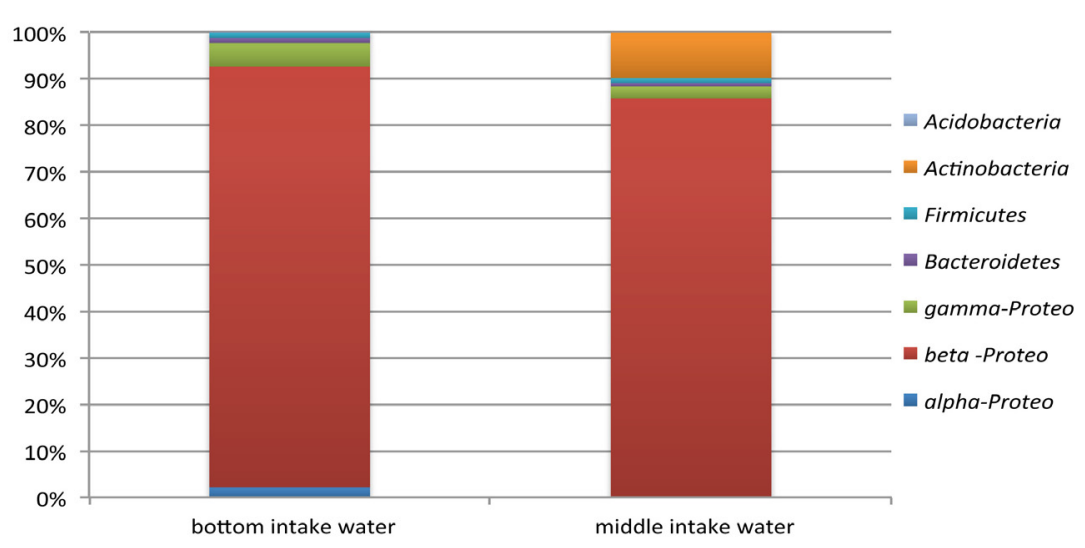

Fig. 4. Bacterial profiles at the bottom of the Intake water and in the middle of the Intake water. Fig. 4. Profils bactériens au plus profond et au milieu de la prise d'eau.

highly present in soil, where they can represent up to $25-30 \%$ of identified $16 \mathrm{~S}$ sequences. Microscopic observations and Gram determination of colonies isolated in 2011 (data not shown) revealed the presence of bacteria that could belong to these groups.

\subsubsection{Microbial properties of the Intake water-RES9}

Biofilms form at the interface between a substratum and water. In order to evaluate the relationship between the Intake water and the biofilm composition in the Penstock, bacterial profiles of the Intake water (RES9) were first determined.

It clearly appears that Proteobacteria is the predominant bacterial group, and among them, beta-Proteobacteria represents $88.1 \pm 3.4 \%$ of all Proteobacteria in the Intake water (Fig. 4). Even though only 2 water samples were made, results show that profiles in both locations are different, i.e. Actinobacteria were only detected in the "Middle" Intake sample $(9.8 \%$ in "Middle Intake" versus $0.0 \%$ in the "Bottom Intake" sample).

\subsubsection{Biofilm composition in the different parts of the Penstock and evolution according to time}

Microscopic observations revealed that biofilms contain amorphous particles and crystals. The level of free bacteria was $10^{10}$ to $10^{11}$ bacteria $\mathrm{g}^{-1}$. The level of eukaryotic cells was inferior to $10^{6}$ cells $\mathrm{g}^{-1}$, mostly dead (stained by Trypan Blue). A clear loss of viability was also observed for bacteria during the water drainage (more than $50 \%$ on January the 16th).

The semi-quantification method (by microscopy) and qPCR results did not give the same results: a difference of 2-log bacteria per gram was observed. However, microscopic observations 


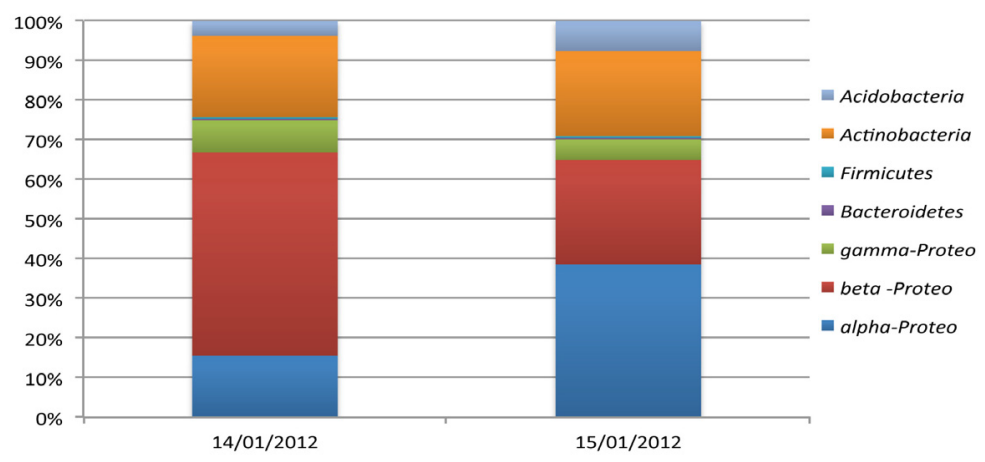

Fig. 5. Variation with time of bacterial groups in the complete biofilm of the HR section.

Fig. 5. Variation au cours du temps des grands groupes bactériens dans le biofilm complet de la section HR.

may have overestimated bacterial concentrations because of the presence of a complex and dense mineral matrix (see Sect. 3.3). Secondly, even though qPCR was made according to controlled and recognized methods, its yield is affected by the DNA extraction step. DNA extraction includes a lysis step to break bacterial cells and allow access to the DNA. This step can be altered by the presence of extracellular matrix components and/ or differences in cell wall properties according to bacterial species. However, as previously observed by microscopic observations, total bacterial concentrations measured by qPCR did not vary significantly among biofilm samples during the water drainage.

\subsubsection{In the HR section}

The structure of the biofilm presented 2 layers. Considering these differences, bacterial profiles were analysed in the upper layer and complete biofilm and according to the time of the water drainage.

First, results show that bacterial profiles differed in the upper and the complete biofilm on the initial sampling day. Beta-Proteobacteria was the major bacterial group. It represented $51.3 \%$ of the bacterial population in the complete biofilm (Fig. 5) and $86.7 \%$ in the upper biofilm (Fig. 6); a proportion that is highly similar to that of the intake water (Fig. 4). The proportion of alpha-Proteobacteria, gamma-Proteobacteria, Actinobacteria and Acidobacteria was also higher in the complete biofilm than in the upper biofilm, indicating a lower biodiversity in the upper biofilm layer.

On the second day of water drainage, bacterial profiles were significantly different than the previous day. The proportion of beta-Proteobacteria decreased by half in the complete and upper biofilm $(51.3 \%$ versus $26.3 \%$ in the complete biofilm; $86.7 \%$ versus $43.6 \%$ in the upper biofilm). On the contrary, the proportion of alpha-Proteobacteria, 


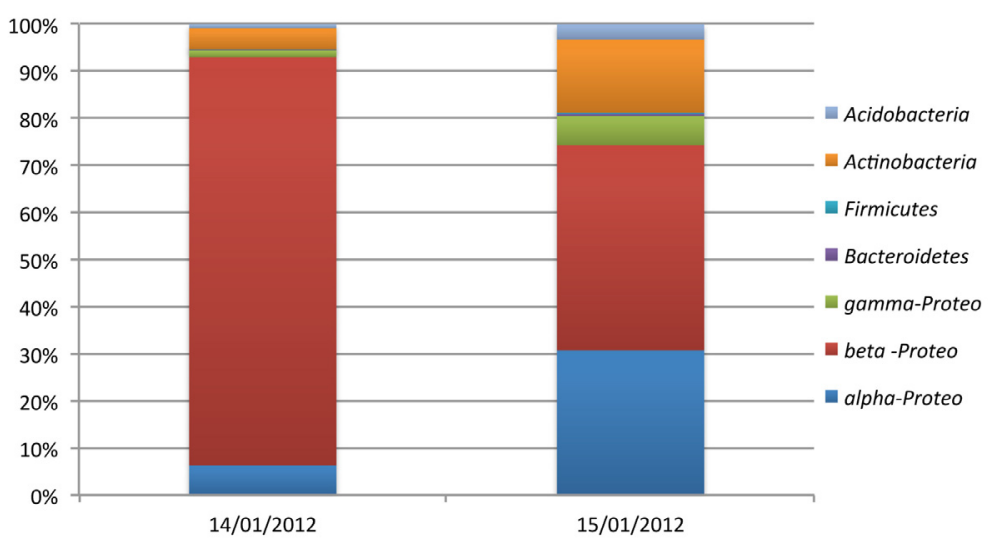

Fig. 6. Variation with time of bacterial groups in the upper biofilm of the HR section.

Fig. 6. Variation au cours du temps des grands groupes bactériens dans la partie supérieure du biofilm de la section HR.

Actinobacteria and Acidobacteria increased in the biofilm, resulting in a high biodiversity in both layers of the biofilm after $24 \mathrm{~h}$ of water drainage.

It is also interesting to note that the water drainage not only affected bacterial profiles, but also the viability. During the sampling campaign, a loss of viability was observed in the HR section according to time, as indicated by the increase of blue cells observed microscopically (no dead bacteria detected in samples in $\mathrm{HR}$ on the 14th of January; 25 to $50 \%$ of dead bacteria $24 \mathrm{~h}$ after the beginning of water drainage).

\subsubsection{In HP section}

\subsubsection{Upper versus complete biofilm} in the concrete HP section

As for the HR section, samples of the upper biofilm and the complete biofilm were analysed on the first sampling day (Fig. 7).
Interestingly, profiles of the upper layer and complete biofilms were similar. Indeed, the proportions of alphaand beta-Proteobacteria (the major groups, representing $57 \%$ of the bacterial population) varied by less than $15 \%$. It is interesting to note that the proportion of beta-Proteobacteria was significantly different to that of the intake water and this group was not predominant in HP biofilm, contrary HR biofilms.

\subsubsection{Impact of the material on biofilm composition}

The HP sampling site consists of 2 types of materials: concrete and galvanized steel coated with an anti-corrosive paint. Samples were taken on both materials in order to analyse the impact on the biofilm.

On the concrete HP part, bacterial proportions changed with time (Fig. 8): the beta-Proteobacteria proportion increased significantly (+16\%), whereas 


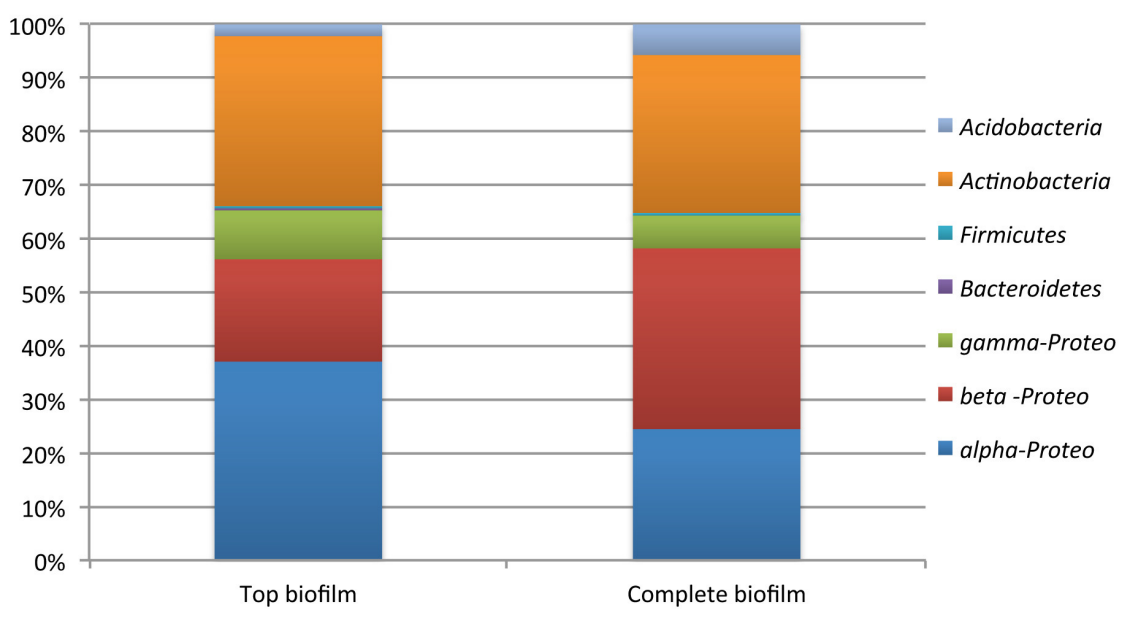

Fig. 7. Bacterial profiles in the concrete part of the HP Tunnel in the upper and complete biofilm.

Fig. 7. Profils bactériens dans la partie supérieure et le biofilm complet sur le béton du Tunnel HP.

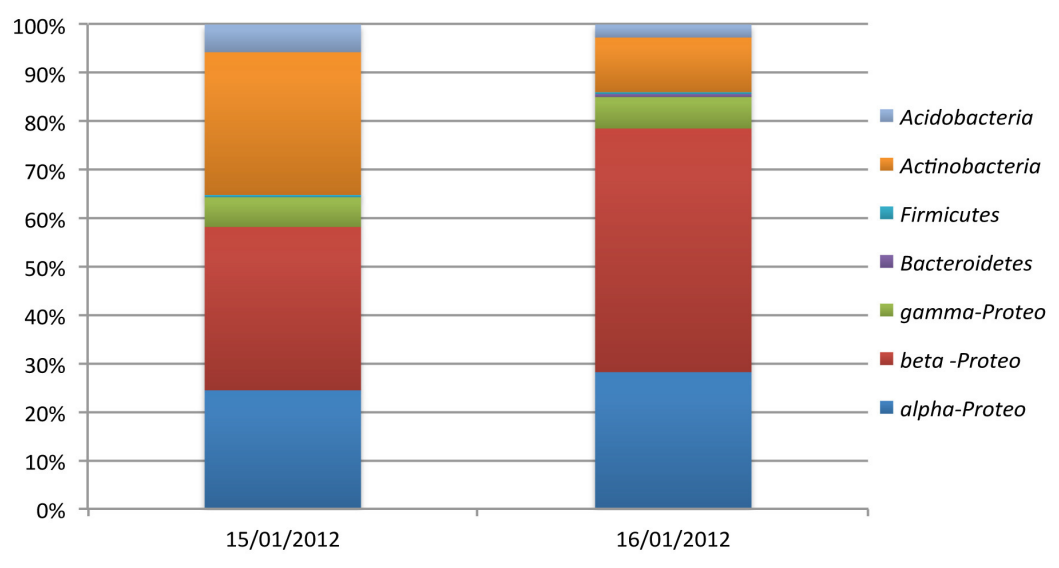

Fig. 8. Variation with time of bacterial groups in the biofilm formed on concrete of the HP section.

Fig. 8. Variations au cours du temps des grands groupes bactériens dans le biofilm formé sur le béton de la partie HP.

the Actinobacteria proportions decreased from the first to the second day $(-18 \%)$. On the contrary, all bacterial groups were stable in the biofilm formed on the galvanized steel (less than $5 \%$ of variation in every group; Fig. 9).

In parallel, on both types of material, the percentage of dead cells increased from 25 to $50 \%$ (data not shown). 


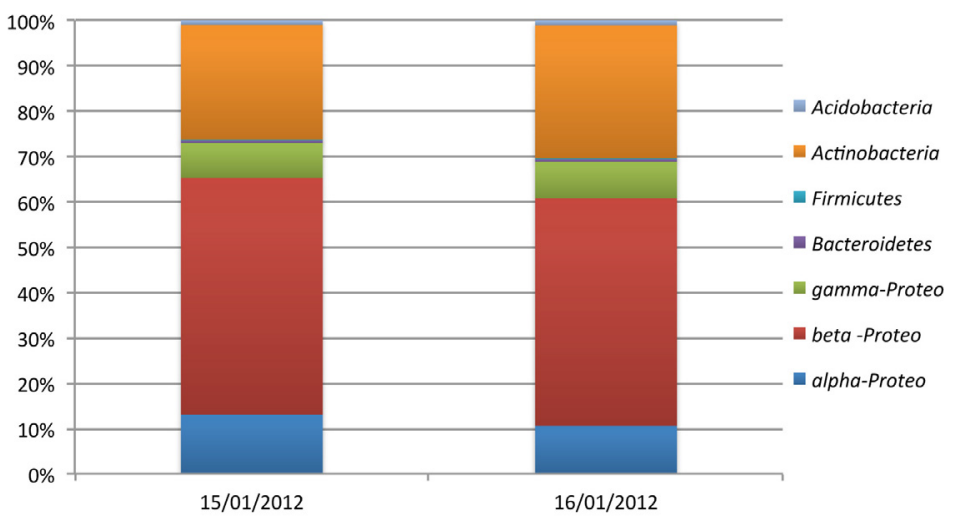

Fig. 9. Variation with time of bacterial groups in the biofilm formed on galvanized steel of the HP section.

Fig. 9. Variations au cours du temps des grands groupes bactériens dans le biofilm formé sur l'acier galvanisé de la section HP.

\section{DISCUSSION}

\subsection{Relationship between the mineral and the microbiological parts of the biofilm}

In the Penstock, the only known source of iron comes from the Intake. High concentrations of iron (reservoir average up to $11.5 \mathrm{mgFe} \mathrm{L}^{-1}$, predominantly occurring as $\mathrm{Fe}^{2+}$ ) have been reported in Chanudet et al. (same issue) in the bottom of the reservoir during periods of thermal stratification (March to October). In fact, reservoir thermal stratification and anoxia in the bottom waters of the reservoir promote the reduction of insoluble iron $\left(\mathrm{Fe}^{3+}\right)$ in the sediment/soil particulate phase to soluble iron $\left(\mathrm{Fe}^{2+}\right)$. Then, the dissolved $\mathrm{Fe}^{2+}$ moves into the reservoir bottom waters and increases their iron concentrations. This may be the source of iron for the formation of Lepidocrocite in the Headrace Tunnel. As the iron rich, anoxic reservoir bottom water enters into the Intake, it mixes with oxygenated surface water. This may be the source of the oxygen that oxidizes iron into crystallized Lepidocrocite. However, the insoluble iron $\left(\mathrm{Fe}^{3+}\right)$ may also directly originate from the reservoir water since this iron species occurs, in a very small extent as dissolved ions. It means that oxygen may not be needed to get some iron at the right oxidation state in the biofilm. The order of magnitude of total mass of deposited iron $\mathrm{Fe}^{3+}$ assuming the few millimetres thick biofilm is homogeneously mineralized on the inner cylindrical Penstock of $2642 \mathrm{~m}$ length (1500 m for HR plus $1142 \mathrm{~m}$ for HP) has been estimated at 1 ton of $\mathrm{Fe}^{3+}$. This value represents only $0.03 \%$ of the total dissolved iron flux (2900 ton) that flows through the Intake between March 


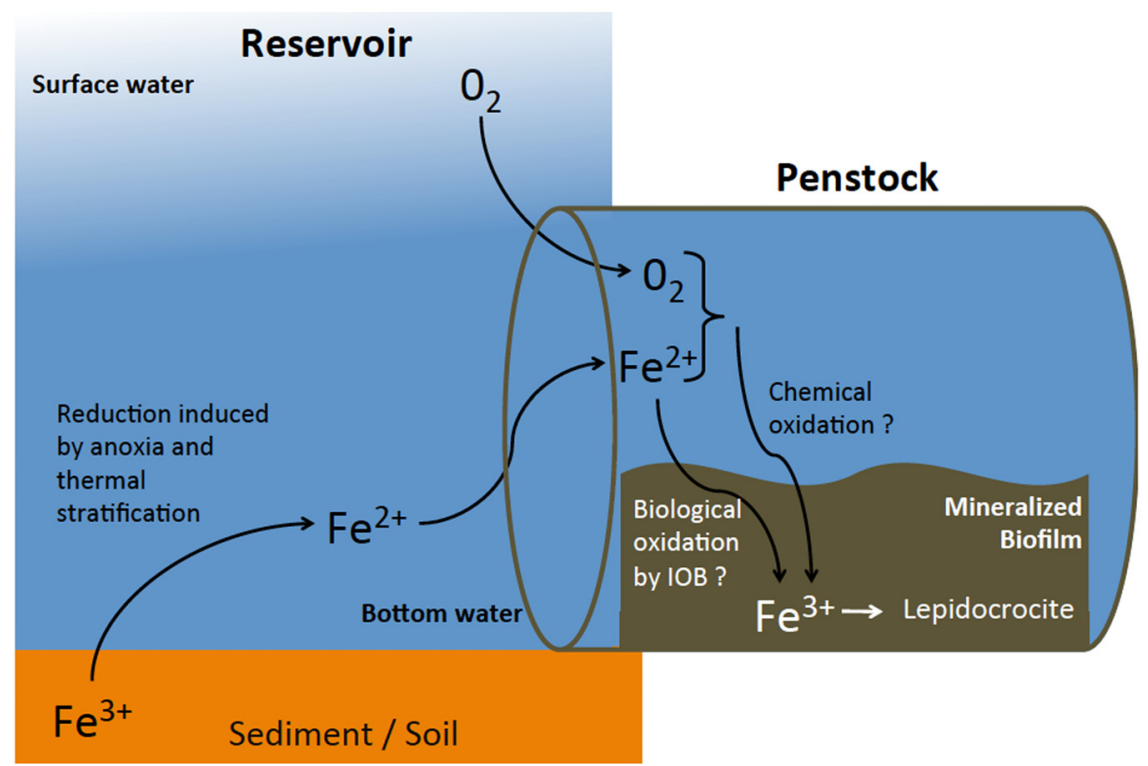

Fig. 10. Hypothetical origin of the iron mineralization in the biofilm in the NT2 Penstock.

Fig. 10. Hypothèse sur l'origine de la minéralisation du fer dans la conduite forcée de NT2.

2010 (start of test operation) and January 2011 (first water drainage) $\left([\mathrm{Fe}]_{\text {moy }}=0.48 \mathrm{mgFe} \mathrm{L}^{-1}\right.$ and $\mathrm{Q}_{\text {moy }}=$ $\left.215.5 \mathrm{~m}^{3} \mathrm{~s}^{-1}\right)$. Even if the total iron concentration in the reservoir is likely to decrease with time, the iron stock available for the biofilm development will remain high. It means that preventing such a biofilm accumulation may be complex (drastic change in $\mathrm{pH}$, oxidation state and/or iron content in large volumes of water) considering industrial and environmental constraints.

As observed macroscopically, the biofilm was highly mineralized. The thermodynamics and kinetics of the mineralization process are still unclear. In particular, it is not known whether the adhesion of bacteria triggers/enhances the deposition of oxide-hydroxides and speed up its kinetics. For instance, iron-oxidizing bacteria (IOB), including
Acidovorax sp., Aquabacterium sp. or Thermomonas $s p$. can derive energy from the oxidation of $\mathrm{Fe}^{2+}$, usually soluble, to $\mathrm{Fe}^{3+}$ (Straub et al., 2004). IOB have diverse phylogenies, like Firmicutes or Nitrospirae, but most of them belong to the Proteobacteria phylum (Hedrich et al., 2011), which is in agreement with our results. $\mathrm{Fe}^{3+}$ is poorly soluble and may precipitate as various iron oxi-hydroxides, including Goethite and Lepidocrocite, in specific geochemical conditions (Larese-Casanova et al., 2010). The authors demonstrated that biological $\mathrm{Fe}^{2+}$ oxidation is influenced by the $\mathrm{pH}$ and phosphate concentration. Figure 10 shows a hypothetical iron cycle that could occur in the NT2 Penstock, involving the biofilm.

In a geological context, Magnesioferrite is representative of hydrothermalism. In the present context of 
industrial conditions, it may be due to mineral transformations linked to the pressure increase along the Penstock. The mineralogical transformation of Lepidocrocite into Magnesioferrite with the pressure increases also remains an open question.

Further experimental studies will lead to a better understanding of the kinetics and the biological, physical and chemical thermodynamics conditions required to form such a biofilm with specific mineralogical properties.

\subsection{Evolution of the biofilm during the 2012 water drainage}

Even though this study is based on a low number of samples, due to the limited access to the Penstock, interesting observations could be made concerning biofilm behaviour, considering the poor literature on this type of water plant versus drinking water systems. This study also shows that bacterial profiles, correlated to bacterial viability, are good indicators of the state of the biofilm inside the NT2 Penstock.

In general, three parameters impact the biofilm composition: (i) the biofilm layer, (ii) the surface material and (iii) the Penstock water drainage. The influence of all parameters is sketched in Figure 11, according to their importance.

Beta-Proteobacteria were the predominant population in water and biofilm samples. These bacteria are consistently re-injected in the Penstock via the water Intake and influence the composition of the upper biofilm layer. One can hypothesize that this population is also more resistant to operating conditions in the Penstock (pressure, shear stress). They were also an interesting population to study since their proportion decreased when the biofilm was affected. The dominance of Proteobacteria has been earlier demonstrated in many studies on water plants, including drinking water distribution systems (Jang et al., 2012). In a study published in 2008, Barton et al. also noticed the predominance of Proteobacteria in the biofilm of a hydroelectric plant in Tasmania, and more specifically alpha-Proteobacteria and Chloroflexi. In the present study, the operating conditions (flow, pipe diameter, water characteristics and temperature) in both sites are very different and may have led to differences in the biofilm composition. Douterelo et al. (2013) have recently described the bacterial profiles of water and biofilm in an experimental drinking water distribution system. They demonstrated a predominance of gamma- and beta-Proteobacteria in the biofilms, while alpha-Proteobacteria were predominant in bulk water samples. They linked the biofilm enrichment in gammaand beta-Proteobacteria to the properties of some bacteria inhabiting the biofilm like Pseudomonas, Zooglea and Janthinobacterium to express extracellular polymeric substances and to adhere to surfaces and favour coaggregation between cells. In our case, it can be hypothesized that some of these bacteria are present in the water Intake and so exist in the biofilm, specifically in the upper layer.

As we demonstrated, the material affects biofilm composition and behaviour. Implication on bacterial attachment on the inner surface of the pipe system is based on surface characteristics and stability (Pedersen, 1990; 


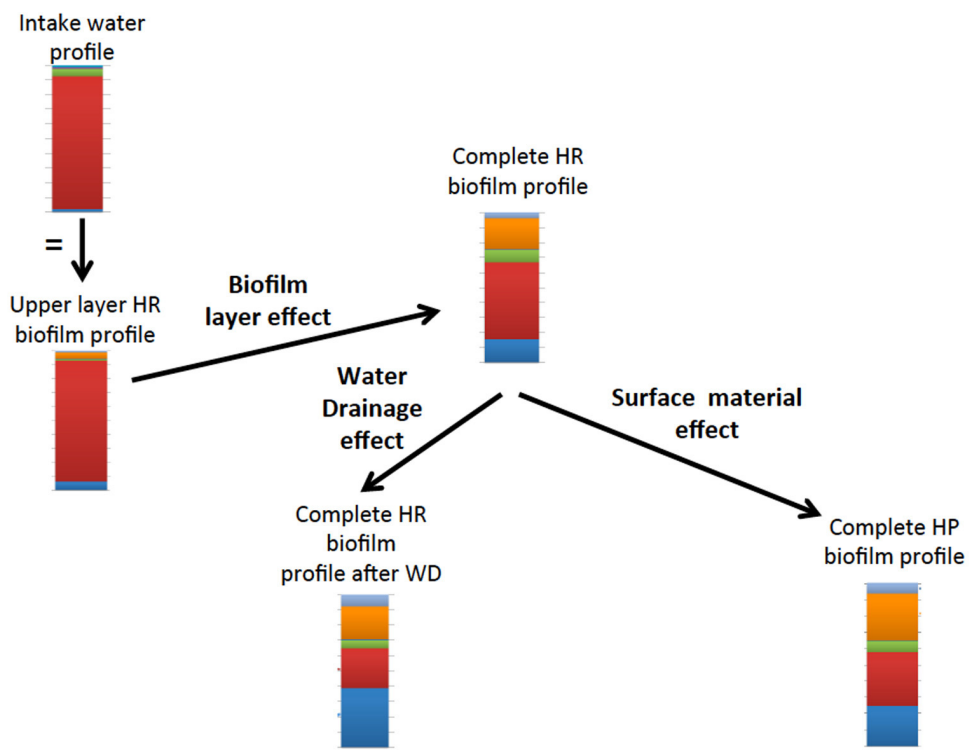

Fig. 11. Parameters impacting the biofilm composition in the NT2 Penstock. WD = water drainage.

Fig. 11. Paramètres influençant la composition du biofilm dans la conduite forcée du barrage NT2. WD = vidange de la conduite.

Percival et al., 1998; Niquette et al., 2000). The biofilm growth is also affected (Schwartz et al., 1998; Lehtola et al., 2004), resulting in increased bacterial concentration, species diversity and corrosion of the pipe (Jang et al., 2012). It is important to note that most of these previous studies are based on culture-dependent methods. In such conditions, no or few differences were noted on microbial quantities between the pipes materials. Molecular techniques offer new approaches for the determination of biofilm composition, more specifically viable but non-cultivable microorganisms or VBNC (NeriaGonzalez et al., 2006; Jang et al., 2012) or microbial activity via metabolomics (Beale et al., 2013). This was confirmed by our results on cultures performed during the 2011 campaign with no significant difference between the samples and qPCR analysis performed during the 2012 campaign underlying dramatic modification in biofilm contents. The precise identification of bacteria present in both biofilms would be the next step to determine how material can affect the microbial colonization.

The water quality, such as temperature, is also of concern in the biofilm development (Frias et al., 2001; Jang et al., 2012). In our conditions, temperatures are favourable for microbial growth. Another important factor in the biofilm composition is the presence of nutrients in the water intake, like organic carbon (Camper et al., 1998; Frias et al., 2001) or the importance of $\mathrm{Fe}^{3+}$. Bacteria able to use $\mathrm{Fe}^{3+}$ belong to various groups including the dominant one 
observed in this study (beta-Proteobacteria). Jang et al. (2012) have recently studied the effect of phosphate addition on biofilm communities on stainless steel and ductile cast iron (DCI) pipes. The molecular analysis indicates the dominance of Proteobacteria (50\%), followed by Firmicutes (10\%) and Actinobacteria (2\%). Differences occur at the genus level with a dominance of Bradyrhizobium on corroded DCI pipes. The impact of phosphate on the biofilm diversity was also demonstrated, but in our study, the phosphate level was low.

\subsection{Potential biofilm elimination processes}

In order to avoid biofilm, it is necessary to understand its development. Biofilm development follows a 3-step cycle: the attachment stage when planktonic cells ("swimming" cells of the bulk phase) are transferred onto a substratum; the growth stage, which corresponds to cell division and leads to the formation of microcolonies; the detachment of bacteria when cells are released in the environment. In general, methods to control the biofilm target one of these steps. For instance, reducing bacterial adhesion can consist in selecting or treating materials, lowering the entry of microorganisms in a system by acting on the water quality: the adjunction of residual disinfectant in water (i.e. chlorine $<1 \mathrm{mg} \mathrm{L}^{-1}$ ) or microfiltration is a way to limit the bacterial intake in potable water systems.

The nature of the substratum is known to influence the biofilm composition. It was also the case in the present study, where results underlined a major difference in the biofilm composition and structure between concrete and galvanized steel coated with a protective paint against corrosion. The literature describes the successful use of antifouling paints on ship hulls, where it prevents for formation of biofilms and surface colonization by higher organisms that could affects the ships performance (Van Mooy et al., 2014). The use of such antifouling paintings in penstocks appears interesting, however the maintenance needed (reapplication of paint) and the long term efficacy should be evaluated. Taking into account the limited possibility to modify the Penstock at this time, a surface treatment does not appear to be a relevant solution.

Acting on parameters allowing bacterial growth can also impair biofilm development. Norton \& LeChevallier (2000) for instance, demonstrated that it is possible to reduce biofilm proliferation by lowering the Assimilable Organic Carbon (AOC) concentration with biologically active filters. Similarly, the concentration of specific nutrients (phosphorus, nitrogen, etc.) can be lowered with Fluidized Bed Biofilm Reactors. Temperature is also an important parameter for biofilm proliferation. Temperatures comprised between 25 and $35^{\circ} \mathrm{C}$ are typically the most favourable for bacterial development. Kusnetsov et al. (1997) showed that lowering the water temperature in a cooling tower decreased Legionella pneumophila concentration. The warm water temperatures observed on the NT2 hydropower plant might favour biofilm proliferation. However, temperature is not a parameter that can be modified at the NT2 Penstock and any increase or 
decrease would also have important consequences for the environment.

Finally, biofilm detachment can be achieved by cleaning and/or disinfection episode(s). According to the "Best Practice Catalogue for Penstocks and Tunnels" edited by the MESA Associates, Inc., and Oak Ridge National Laboratory, scrubbing and cleaning is a good way to decrease surface roughness and limit head losses in Penstocks (Oakridge National Laboratory, 2011). Barton et al. (2008) also demonstrated that the regular cleaning of pipelines is economically beneficial for hydroelectric plants. However, this solution can be costly and involves extensive production stops.

So far, the water drainage of the NT2 Penstock seems to be the most convenient technique to improve head losses of the system. Draining the Penstock leads to variation in the biofilm viability and population profiles; the long-term analysis of head losses will bring more information on the efficiency of the method. In general, it was observed that water drainage was a controllable parameter allowing the modification of the biofilm composition in the Penstock: two days after the drainage, a diversification of microbial populations was observed in the biofilm (decrease of beta-Proteobacteria at the benefit of Actinobacteria, Acidobacteria, alphaProteobacteria, gamma-Proteobacteria) as well as a loss of biofilm viability. It appears that operating conditions of the Penstock are unfavourable for the development of a number of microorganisms. Water drainage allows a return to atmospheric pressure, higher oxygen availability without any shear stress in the Penstock, which probably favours the growth of some bacterial species and leads to a higher biodiversity in the biofilm after two days of drainage. It is likely that the return to operating conditions in the Penstock is harmful for a number of these microorganisms. Most probably, these unfit microorganisms are quickly removed from the biofilm, which leads to a weakening and/ or erosion of the biofilm. This phenomenon could explain the decrease of head losses after the Penstock water drainage. The study of Douterelo et al. (2013) is very interesting regarding the influence of hydraulic regimes on bacterial biofilm communities. Using an experimental drinking water distribution system, they observed that flushing altered the pipe-wall bacterial community structure without complete removal of bacteria from the pipe surfaces, even under highly varied flow conditions. Knowing that, water drainage may be considered as more efficient in biofilm control than modification in hydraulic regimes. Once head losses caused by the biofilm are stabilized and deemed to be within an acceptable range of values, water drainage does not appear to be relevant. A study of the balance of organic versus mineral composition of the biofilm and bacterial viability (by ATPmetry, viability PCR or cytometry) would be interesting in order to give new information about the impact of the water drainage.

It is important to note that contrary to the biofilm formed on reinforced concrete, the biofilm formed on galvanized steel in HP was poorly affected by the water drainage. However, it was noticed previously that biofilm formed on that part was less thick and smoother than the biofilm formed on concrete; hence it is probably less responsible for head losses. 
Since hydrodynamic solutions to control biofilm formation (including WD) are difficult to implement and considering the potential direct link between the microbial profile of water Intake and those of pipe biofilms, a survey of the water Intake composition would be of interest to anticipate biofilm modification in composition.

\section{ACKNOWLEGEMENTS}

We are grateful to Water Quality and Biodiversity Department (AE Lab) technical staff for their daily efforts to fulfill samplings and analyses and provide a consistent water quality monitoring. We also would like to thank EDF and NTPC in providing all logistics, safety requirements, all useful information/knowledge (Technical Department of NTPC), and the time needed to perform such a study. Their dedication to science while operating heavy maintenance work should be underlined.

\section{REFERENCES}

Bacchetti De Gregoris T., Aldred N., Clare A.S. \& Burgess J.G., 2011. Improvement of phylum- and class-specific primers for real-time PCR quantification of bacterial taxa. $J$ Microbiol. Methods 86(3) : 351-356.

Barton A.F., Wallis M.R., Sargison J.E., Buia A. \& Walker G.J., 2008. Hydraulic roughness of biofouled pipes, biofilm character, and measured improvements from cleaning. J Hydraulic EngineeringAsce 134(6) : 852-857.

Beale D.J., Barratt R., Marlow D.R., Dunn M.S., Palombo E.A., Morrison P.D. \& Key C., 2013. Application of metabolomics to understanding biofilms in water distribution systems: a pilot study. Biofouling 29(3) : 283-294.

Camper A., Burr M., Ellis B., Butterfield P. \& Abernathy C., 1998. Development and structure of drinking water biofilms and techniques for their study. J. Appl. Microbiol. 85 Suppl. 1 : 1S-12S.

Chanudet V., Guédant P., Rode W., Godon A., Guérin F., Serça D., Deshmukh C. \& Descloux S. Evolution of the physicochemical water quality in the Nam Theun 2 Reservoir for the first 5 years after impoundment. Hydroécol. Appl. 19 (same issue).

Deer W.A., Howie R.A. \& Zussman J., 2013. An introduction to the rock-forming minerals. The Mineralogical Society (3rd edition), London, $498 \mathrm{p}$.

Descloux S., Guédant P., Phommachanh D. \& Luthi R. Main features of the Nam Theun 2 hydroelectric project (Lao PDR) and the associated environmental monitoring programme. Hydroécol. Appl. 19 (same issue).

Douterelo I., Sharpe R.L. \& Boxall J.B., 2013. Influence of hydraulic regimes on bacterial community structure and composition in an experimental drinking water distribution system. Water Res. 47(2) : 503-516.

Fierer N., Jackson J.A., Vilgalys R. \& Jackson R.B., 2005. Assessment of soil microbial community structure by use of taxon-specific quantitative PCR assays. Appl. Environ. Microbiol. 71(7) : 41174120.

Frias J., Ribas F. \& Lucena F., 2001. Effects of different nutrients on bacterial growth in a pilot distribution system. Antonie Van Leeuwenhoek International Journal of General and Molecular Microbiology 80(2) : 129-138.

Hedrich S., Schlomann M. \& Johnson D.B., 2011. The iron-oxidizing proteobacteria. Microbiol.-Sgm 157 : 1551-1564. 
Jang H.J., Choi Y.J., Ro H.M. \& Ka J.O., 2012. Effects of phosphate addition on biofilm bacterial communities and water quality in annular reactors equipped with stainless steel and ductile cast iron pipes. J. Microbiol. 50(1) : 17-28.

Kusnetsov J.M., Tulkki A.I., Ahonen H.E. \& Martikainen P.J., 1997. Efficacy of three prevention strategies against legionella in cooling water systems. J. Appl. Microbiol. 82(6) : 763-768.

Larese-Casanova P., Haderlein S.B. \& Kappler A., 2010. Biomineralization of lepidocrocite and goethite by nitratereducing $\mathrm{Fe}(\mathrm{II})$-oxidizing bacteria: Effect of $\mathrm{pH}$, bicarbonate, phosphate, and humic acids. Geochimica Cosmochimica Acta 74(13) : 3721-3734.

Lehtola M.J., Miettinen I.T., Keinanen M.M., Kekki T.K., Laine O., Hirvonen A., Vartiainen T. \& Martikainen P.J., 2004. Microbiology, chemistry and biofilm development in a pilot drinking water distribution system with copper and plastic pipes. Water Res. 38(17) : 37693779.

Neria-Gonzalez I., Wang E.T., Ramirez F., Romero J.M. \& Hernandez-Rodriguez C., 2006. Characterization of bacterial community associated to biofilms of corroded oil pipelines from the southeast of Mexico. Anaerobe 12(3) : 122-133.

Niquette P., Servais P. \& Savoir R., 2000. Impacts of pipe materials on densities of fixed bacterial biomass in a drinking water distribution system. Water Res. 34(6) : 1952-1956.

Norton C.D. \& LeChevallier M.W., 2000. A pilot study of bacteriological population changes through potable water treatment and distribution. Appl. Environ. Microbiol. 66(1): 268-276.

Oakridge National Laboratory M., 2011. Best Practice Catalog-Penstocks and tunnels. Hydropower Advancement Project.

Pedersen K., 1990. Biofilm Development on Stainless-Steel and Pvc Surfaces in Drinking-Water. Water Res. 24(2) : 239-243.

Percival S.L., Knapp J.S., Edyvean R.G.J. \& Wales D.S., 1998. Biofilms, mains water and stainless steel. Water Res. 32(7) : 2187-2201.

Schultz M.P. \& Swain G.W., 2000. The influence of biofilms on skin friction drag. Biofouling 15(1-3) : 129-139.

Schwartz T., Hoffmann S. \& Obst U., 1998. Formation and bacterial composition of young, natural biofilms obtained from public bank-filtered drinking water systems. Water Res. 32(9) : 2787-2797.

Stoodley P., Dodds I., Boyle J.D. \& LappinScott H.M., 1998. Influence of hydrodynamics and nutrients on biofilm structure. J. Appl. Microbiol. 85 Suppl. 1 : 19S-28S.

Straub K.L., Schonhuber W.A., BuchholzCleven B.E.E. \& Schink B., 2004. Diversity of ferrous iron-oxidizing, nitratereducing bacteria and their involvement in oxygen-independent iron cycling. Geomicrobiol. J. 21(6) : 371-378.

Van Mooy B.A., Hmelo L.R., Fredricks H.F., Ossolinski J.E., Pedler B.E., Bogorff D.J. \& Smith P.J., 2014. Quantitative exploration of the contribution of settlement, growth, dispersal and grazing to the accumulation of natural marine biofilms on antifouling and fouling-release coatings. Biofouling 30(2) : 223-236. 